Egyptian Journal of Aquatic Biology \& Fisheries

Zoology Department, Faculty of Science,

Ain Shams University, Cairo, Egypt.

ISSN $1110-6131$

Vol. 23(1): 413 - 426 (2019)

www.ejabf.journals.ekb.eg

\title{
Effects of Diatoms Amphora coffeaeformis on growth parameters, non specific immunity and protection of the Nile tilapia (Oreochromis niloticus) to Aeromonas hydrophila infection
}

\author{
Hala F. Ayoub ${ }^{1 *}$ Mohamed F. Abdelghany ${ }^{2}$, and Abo El-Khair B. El-Sayed ${ }^{3}$ \\ 1- Fish Health and Diseases department, Central Lab. for Aquaculture Research, \\ Abbassa, Sharkia, Egypt. \\ 2- Fish Production Department, Al-Azhar University, Cairo, Egypt. \\ 3 - Algal Biotechnology Unit, National Research Centre, Dokki, Cairo, Egypt. \\ *Corresponding Author: dr.halakg@ hotmail.com
}

ARTICLE INFO

Article History:

Received: April. 20, 2019

Accepted: May. 25, 2019

Online: June 20, 2019

Keywords:

Amphora coffeaeformis

Nile tilapia

Growth performance

Non-specific immunity

Aeromonas hydrophilia

\begin{abstract}
Eight weeks feeding trial was carried out to assess the growth promoting and the immune-stimulatory effects of the supplementation of Amphora coffeaeformis (A. coffeaeformis) in the Nile tilapia diets and its resistance to bacterial infections. Fish were fed on diet containing 0,10 , 20 and $30 \mathrm{~g}$ of $A$. coffeaeformis per $\mathrm{kg}$. Growth performance parameters and body composition of experimental fish were evaluated. Serum protein profile (albumin, globulin, total protein and $\mathrm{A} / \mathrm{G}$ ratio), serum liver function enzymes, and serum lysozyme were assessed. Therefore, fish in all the experimental groups were challenged with pathogenic Aeromonas hydrophila following the feeding experiment. The results showed that the growth-promoting influence of $A$. coffeaeformis was observed on Nile tilapia performance, the optimum growth and feed utilization were obtained at fish maintained on $10 \mathrm{~g}$ A. coffeaeformis $\mathrm{kg}^{-1}$ diet. A. coffeaeformis supplementation improved the protein and lipid contents in fish bodies without significant differences among them, especially when fed 20 or $30 \mathrm{~g}$ per $\mathrm{kg}$, while no significant differences in the moisture and ash contents were observed among different treatments. As well, the physiological parameters (serum protein profile and serum lysozyme) were improved when fish were fed on A. coffeaeformis enriched diet. Besides, lysozyme activity was giving good results in 10, 20 and $30 \mathrm{~g}$ per $\mathrm{kg}$. Fish mortality after challenged against $A$. hydrophila decreased with increasing $A$. coffeaeformis level in fish diets. These results indicated that $A$. coffeaeformis supplement is promising as an alternative method to antibiotics for disease prevention in Nile tilapia culture, and the optimum level of $A$. coffeaeformis in the fish diet should be ranged between 10 to $20 \mathrm{~g} \mathrm{~kg}^{-1}$ diet.
\end{abstract}

\section{INTRODUCTION}

Production of Nile tilapia (O. niloticus) has been increased significantly in Egypt and most tropical countries (Dhar et al., 2015, Selim and Reda, 2015 and ElSayed, 2006). It is an omnivorous fish that can utilize a wide range of food items including blue-green algae (Getabu, 1994, Gatesoupe, 1999 \& Abdel-Tawwab and El-Marakby, 2004). 
However, the disease has been a primary necessity to the aquaculture industry, imposing massive losses on farming facilities all over the world. Aeromonas hydrophila was considered among the most pathogenic organisms to both homothermic and poikilothermic-hosts including tilapia species (Amin et al., 1985 \& Zaki, 1991).

Antibiotic drugs have the capacity to kill or inhibit the growth of microorganisms. So, the use of antibiotics to control fish disease needs to be limited due to the emergence of drug-resistant bacteria and concerns about environmental hazards and food safety (Serrano, 2005). Therefore, several alternative strategies to the use of antimicrobials have been proposed such as the use of probiotics as biological control agents. Also, probiotics are live microbes that may serve as dietary supplements to improve fish growth and immune responses, have received some attention in aquaculture (Irianto and Austin, 2002). Recently, the researchers have been targeted to search in nature to find acceptable and economically viable natural products be suitable for treating various chronic diseases.

Marine algae exhibit different biological activities as a result of the presence of a variety of useful phytoconstituents (Barros et al., 2005). The primary or secondary metabolites that are synthesized under the action of the metabolic enzymes have been isolated to be developed as an effective alternative to antibiotics to be gained importance specially to combat disease problem (Selvendran, 2013). It is worth to mention that algae can produce like these effective and valuable natural products. Of these are in concern Chlorella, Spirulina and Amphora algae.

For this reason, in recent years, the utilization of algae in pharmaceutical applications has attracted global attention (Enwereuzoh and Onyeagoro, 2014). Amphora coffeaeformis (Agardh) Kutzing is one of the most frequently abundant species in alkaline fresh and brackish-water localities (Bhosleac et al., 1993).

Therefore, the present study was conducted to determine the effect of various concentration of $A$. coffeaeformis as a feed additive in the fish diet on growth performance, feed utilization, non-specific immune responses parameters, liver functions enzymes and resistance of Nile tilapia to A. hydrophilia infection.

\section{MATERIALS AND METHODS}

\section{Diatom Amphora coffeaeformis: -}

The Bacillariophyta diatom A. coffeaeformis was locally isolated from drainage water of Ismailia Governorate (El-Sayed, 2006). F2 nutrient solution media was used for laboratory growth, while outdoor mass production was performed within semiclosed photobioreactor with a final capacity of $1200 \mathrm{l}$. The outdoor nutrient solution was made from commercial fertilizers compounds. The biomass was obtained and cleaned by sequenced water washing and centrifugation to remove all the accompanying matters. Consequently, the biomass was recovered and freeze-dried and hence stored as separated species at- $20^{\circ} \mathrm{C}$ until use. The algal material ground to be a fine powder and analyzed.

\section{Diet preparation: -}

Four diets were prepared by thoroughly mixing the ingredients composed of fish meal, soybean meal, corn flour, yellow corn, vitamins, minerals and carboxymethyl-cellulose (Table 1). Amphora biomass was massively produced by Algal Biotechnology Unit, National Research Centre, Egypt. In preparing diets, dry ingredients were first ground to small particle size and homogenized in a food mixer and then warm water was added to the mixture at the ratio of $30 \%$ for pelleting. Diets 
were passed through a mincer machine with a diameter of $3 \mathrm{~mm}$ and were sun dried for 2 days. All diets were formulated to be $30.1 \%$ crude protein and about $3800 \mathrm{kcal}$ metabolizable energy $/ \mathrm{kg}$ diet. Tilapia fed the pelleted diets at a daily rate of $3 \%$ of total biomass 6 days /week (twice daily at 9.00 am and $3.00 \mathrm{pm}$ ), and the amount of feed was weekly adjusted according to the changes in body weight throughout the experimental period ( 8 weeks).

Fish culture and feeding regime: -

A total number of 240 Nile tilapia fingerlings with an average body weight of $7.88 \pm 0.2 \mathrm{~g}$ were obtained from a commercial hatchery in Kafr Elsheikh governorate. Fish were kept in indoor fiberglass for 2 weeks for acclimation with the laboratory conditions. Fish were randomly distributed at 20 fish per $100 \mathrm{~L}$ aquarium and equally divided into four equal treatments in twelve glasses aquaria, with three replicates, each contained 20 fish. Fish were fed on diets 0 (control), 10, 20 and $30 \mathrm{~g}, A$. coffeaeformis per kg diet represent T1 (control), T2, T3 and T4, respectively.

All aquaria were supplied with compressed air via air stones using aquarium air pumps. Wastes of fish were cleaned daily by siphoning with three-quarters of the aquarium's water, which was replaced by aerated water from the storage tank. The temperature of the water range was $26-30^{\circ} \mathrm{C}$. Each diet was fed twice daily, 6 days a week, for a period of 8 weeks. The feeding rate was $3 \%$ of live body weight. Fish were weighed for all groups every 2 weeks and the amounts of feed given were readjusted according to the weight.

The chemical analysis of diets: -

The tested diets and whole fish body from each treatment were analyzed according to the standard methods of AOAC (1990) for moisture, protein, fat, and ash. The moisture content was estimated by drying the samples to a constant weight at $85 \mathrm{c}$ in drying oven (GCA, model 18EM, Precision Scientific group, Chicago, IL, USA).

Table 1: Composition (dry matter \%) of the experimental diets containing different levels of Amphora coffeaeformis.

\begin{tabular}{lcccc}
\multicolumn{1}{c}{ Ingredients \% } & T1 & T2 & T3 & T4 \\
\hline Fish meal & 9.10 & 9.10 & 9.10 & 9.10 \\
Soybean meal & 52.57 & 52.52 & 52.57 & 52.57 \\
Corn flour & 19.25 & 19.30 & 19.25 & 19.25 \\
Starch & 7.00 & 6.00 & 5.00 & 4.00 \\
Corn oil & 1.80 & 1.80 & 1.80 & 1.80 \\
Cod liver oil & 1.98 & 1.98 & 1.98 & 1.98 \\
Vitamin premix & 2.00 & 2.00 & 2.00 & 2.00 \\
Mineral premix & 2.00 & 2.00 & 2.00 & 2.00 \\
a-cellulose & 3.30 & 3.30 & 3.30 & 3.30 \\
Carboxy-methyl-cellulose & 1.00 & 1.00 & 1.00 & 1.00 \\
A. coffeaeformis & 0.00 & 1.00 & 2.00 & 3.00 \\
Total & 100 & 100 & 100 & 100 \\
\hline
\end{tabular}

The nitrogen content was measured using a microKjeldahl apparatus (Labconco, Corporation, Kansas, MO, USA), and crude protein was estimated by multiplying the nitrogen content by 6.25 . The lipid content was determined by ether extraction in a multi-unit extraction Soxhlet apparatus (Lab-Line Instruments, Melrose Park, IL, USA) for $16 \mathrm{~h}$ and ash was determined by combusting dry samples in a muffle furnace (Thermolyne Corporation, Dubuque, IA, USA) at $550{ }^{\circ} \mathrm{C}$ for $6 \mathrm{~h}$. 58 oxygen meter (Yellow Spring Instrument, Yellow Springs, OH, USA).Unionized 
ammonia was measured using DREL/2 HACH kits (HACH, Loveland, CO, USA). The $\mathrm{pH}$ was measured using a $\mathrm{pH}$-meter (Digital Mini-pH Meter, model 55).

Table 2: Chemical analysis of the experimental diets (\% on DM basis)

\begin{tabular}{lcccc}
\hline Parameters & T1 & T2 & T3 & T4 \\
\hline Dry matter (DM \%) & 91.27 & 90.92 & 90.82 & 90.68 \\
Crude protein (\% CP) & 30.16 & 30.12 & 30.08 & 30.04 \\
Crude lipid (\% CL) & 12.99 & 13.38 & 13.00 & 13.22 \\
Crude fiber (CF) \% & 8.32 & 6.89 & 7 & 8.18 \\
Ash\% & 4.44 & 4.42 & 4.43 & 4.41 \\
NFE\% & 44.09 & 45.19 & 45.49 & 44.15 \\
Gross energy (Kcal/ kg) & 4685.07 & 4764.90 & 4739.16 & 4702.65 \\
Digestible energy(Kcal/ kg) & 3513.80 & 3573.67 & 3554.37 & 3526.99 \\
\hline
\end{tabular}

\section{Assessment of the growth performance: -}

Fish samples were collected from each treatment and control groups on the first day and at the end of the experiment to determine growth performance and feed utilization and were calculated as follows:

Weight gain= final weight- initial weight

Body weight gain $(\mathrm{BWG})=(\mathrm{W} 1)-(\mathrm{W} 0)$

Where: W1: means final weight - W0: means initial weight

Condition factor $(\mathrm{K})=$ FW / FL3 $\times 100$

Where: FW: Final body weight (g) FL3: Final body length $(\mathrm{cm} 3)$

Specific growth rate $(\mathrm{SGR}, \%$ / day $)=[\mathrm{Ln} \mathrm{W1}-\mathrm{Ln} \mathrm{W} 0 / \mathrm{T}] 100$

Where: $\mathrm{Ln}=$ the natural $\log \mathrm{W} 1=$ final weight at a certain period $(\mathrm{g})$

$\mathrm{W} 0=$ initial weight at the same period $(\mathrm{g}) \quad \mathrm{T}=$ experimental period (day)

Survival rate $($ SR \%) $=$ Number of fish at final / Number of fish at start X100

\section{Feed efficiency parameters}

The feed conversion ratio $(\mathrm{FCR})=$ Feed intake $(\mathrm{g}) /$ weight gain $(\mathrm{g})$.

Protein efficiency ratio $(\mathrm{PER})=$ Weight gain $(\mathrm{g}) /$ Protein intake $(\mathrm{g})$

Feed efficiency $($ FE \%) $=[$ Weight gain $(\mathrm{g}) /$ Feed intake $(\mathrm{g})] / 100$

Protein productive value $(\mathrm{PPV} \%)=[\mathrm{PR} 1-\mathrm{PR} 0 / \mathrm{PI}] 100$

Where: $\mathrm{PR} 1=$ the total fish body protein at the end of the experiment. (On dry matter basis)

$\mathrm{PR} 0=$ the total fish body protein at the start of the experiment. (On dry matter basis)

$\mathrm{PI}=$ Protein intake.

Energy retention $(\mathrm{ER} \%)=\mathrm{E}-\mathrm{E} 0 / \mathrm{EF} \mathrm{X} 100$

Where: $\mathrm{E}=$ the energy in the fish carcass (kcal) at the end of the experiment.

$\mathrm{E} 0=$ the energy in the fish carcass $(\mathrm{kcal})$ at the start of the experiment.

$\mathrm{EF}=$ the energy $(\mathrm{kcal})$ in feed intake.

\section{Blood sampling:-}

Samples were collected at the beginning of the experiment, 4 weeks, 8 weeks and 10 days after bacterial infection ( $n=5 /$ group/replicate) from caudal blood vessels without anticoagulant (Lied et al., 1975), then centrifuged for $15 \mathrm{~min}$ at $3000 \mathrm{rpm}$ for serum separation to be used for lysozyme assay, total protein, albumin, globulin and liver function enzymes.

\section{Serum lysozyme:-}

Lysozyme concentration was measured according to the method of Schltz (1987), whereas Lysoplate was prepared as $1 \%$ agarose in $0.067 \mathrm{M}$ PBS at $\mathrm{pH} 6.3$. When the temperature of the dissolved agarose lowered to $60^{\circ} \mathrm{C}$, the bacterial uniform suspension (Micrococcus lysodeikticus) was added and mixed well to form a homologous mixture. The mixture was poured in Petri dish at thickness $4 \mathrm{~mm}$. 
Exactly, 251 of serum samples per group were inoculated in a representative well and the plate was incubated at room temperature for 18 hours. The cleared zone ring diameter that has been developed was measured in $\mathrm{mm}$. The concentration of the standard was plotted on the logarithmic axis against the corresponding cleared zones diameter on the linear axis of the semi-logarithmic graph. The diameter of the sample was plotted against the standard for obtaining the lysozyme concentration in $\mathrm{g} / \mathrm{ml}$.

\section{Serum protein profile and liver functions enzymes:-}

Total protein, Albumin, and globulin in fish sera were determined calorimetrically according to Henry (1964). Also, albumin was measured according to Doumas et al. (1971) globulin was determined according to Henry (1964). Moreover, the activities of serum aspartate aminotransferase (AST) and alanine aminotransferase (ALT) were estimated as directed by Reitman and Frankel (1957).

\section{Challenge test:-}

At the end of the study, fish in each aquarium were divided into four groups, $\mathrm{n}=10$ /group/replicate (Abu-Elala et al., 2015). Pathogenic A. hydrophila was injected intraperitoneally with $0.1 \mathrm{ml}$ of $A$. hydrophila $\left(3 \times 10^{5}\right.$ cells $\left.\mathrm{mL}\right)$ which had been previously isolated from moribund fish and identified by the VITEK® 2-C15 automated system for bacterial identification (BioMerieux Inc., France) according to manufacturer's instructions. All injected fish were kept under observation for 10 days to record any abnormal clinical signs and the daily mortality rate.Also, The relative percent survival was calculated according to to (Amend, 1981).

\section{Statistical analysis:}

The data were statistically analyzed by statistical package SPSS version 16 in which data were subjected to one-way ANOVA and Duncan's multiple range test (DMRT) was used to determine the significant differences between the means. Comparisons were made at $5 \%$ probability level.

\section{RESULTS}

\section{Growth performance of Nile tilapia fingerlings: -}

The effect of addition A. coffeaeformis to the diets on growth performance of tilapia (O. niloticus) was shown in Table (3). Results showed that the mean weights and duration of the experiment ranged from $7.88 \pm 0.20 \mathrm{~g}$ for weight, $6.40 \pm 0.30 \mathrm{~cm}$ in length, with slight differences between the experiment indicating that the total randomization of individual fish among the experimental trials at the beginning of the experiment are homogeneous. At the end of the experiment, the final weight was achieved in the experimental diets containing A. coffeaeformis in all concentrations and total body weight $(\mathrm{P}<0.05)$ was lower for control diet than the rest of experimental diets. Also, substantial weight was also noted in an experimental fish fed diets containing A. coffeaeformis $(30 \mathrm{~g}, 20 \mathrm{~g}$, and $10 \mathrm{~g})$ with the average weight of $80.14 \pm 0.9,75.24 \pm 0.91$ and $72.94 \pm 0.83 \mathrm{~g}$, respectively. The averages final rates of fish weights and growth performance showed that all additions showed positive effects on the performance of tilapia (O. niloticus) and improving body weights. Weight gain (WG); daily weight gain (DWG) and specific growth rate (SGR) of the experimental diets which containing A. coffeaeformis algae up to $30 \mathrm{gm} / \mathrm{kg}$ diet were significantly higher $(\mathrm{P}<0.05)$ of those fed fish with $0 \%$ A. coffeaeformis.Diets containing $20 \mathrm{~g}$ of $A$. coffeaeformis (T3) consumed the highest feed than the other treatments giving FCR (1.91), while fish fed on diet containing $30 \mathrm{~g}$ of $A$. coffeaeformis (T4) recorded the best value of FCR (1.75). 
On the other hand, A. coffeaeformis supplementation improved the nutrient utilization, however, fish fed in $10 \mathrm{~g} \mathrm{~A}$. coffeaeformis $\mathrm{kg}$ diet produced the highest PER. Averages of feed utilization in terms of feed intake (FI); daily feed intake (DFI); feed conversion ratio (FCR); feed efficiency (FE); protein efficiency ratio (PER); productive protein value (PPV) and energy retention (ER), On the other hand, experimental fish fed in 10 or $20 \mathrm{~g}$ had significantly higher feed intake $(\mathrm{P}<0.05)$; daily feed intake (FE) and (PER), Whereas the lowest (FI), (DFI), (FE), (PER) and (PPV) were obtained in control groups Table 3.

Table 3: Growth performance and feed utilization paramters (mean \pm SE) of Nile tilapia fed practical diets containing different levels of $A$. coffeaeformis for 8 weeks.

\begin{tabular}{|c|c|c|c|c|}
\hline Parameters & T1 (Control) & $\mathbf{T 2}$ & T3 & T4 \\
\hline Initial. Fish weight (g) & $7.88 \pm 0.20$ & $7.88 \pm 0.20$ & $7.69 \pm 0.30$ & $7.83 \pm 0.30$ \\
\hline Final fish weight (g) & $70.96 \pm 0.24 \mathrm{c}$ & $72.94 \pm 0.83 b c$ & $75.24 \pm 0.91 b$ & $80.14 \pm 0.9 \mathrm{a}$ \\
\hline Initial Fish length $(\mathrm{cm})$ & $6.40 \pm 0.30$ & $6.50 \pm 0.30$ & $6.30 \pm 0.20$ & $6.20 \pm 0.10$ \\
\hline Final fish length $(\mathrm{cm})$ & $14.0 \pm 0.44$ & $14.2 \pm 0.54$ & $14.1 \pm 1.47$ & $13.8 \pm 0.36$ \\
\hline Total weight gain $(\mathrm{g})$ & $63.08 \pm 0.24 \mathrm{c}$ & $65.06 \pm 0.83 b c$ & $67.55 \pm 0.91 b$ & $72.31 \pm 0.9 \mathrm{a}$ \\
\hline AV. Daily gain (g) & $0.55 \pm 0.005 \mathrm{ab}$ & $0.57 \pm 0.010 \mathrm{a}$ & $0.56 \pm 0.005 \mathrm{ab}$ & $0.54 \pm 0.010 b$ \\
\hline SGR (\%/ day $)$ & $2.59 \pm 0.006 b$ & $2.63 \pm 0.010 \mathrm{a}$ & $2.63 \pm 0.01 \mathrm{a}$ & $2.59 \pm 0.010 \mathrm{~b}$ \\
\hline Condition factor $(\mathbf{K})$ & $2.67 \pm 0.24$ & $2.65 \pm 0.29$ & $2.68 \pm 0.81$ & $2.74 \pm 0.28$ \\
\hline Feed intake (g/fish) (FI) & $126.53 \pm 0.89$ & $121.66 \pm 0.34$ & $129.08 \pm 0.771$ & $126.54 \pm 0.854$ \\
\hline Daily Feed intake & $1.05 \pm 0.007$ & $1.06 \pm 0.002$ & $1.07 \pm 0.006$ & $1.05 \pm 0.007$ \\
\hline FCR & $2.00 \pm 0.02 \mathrm{a}$ & $1.87 \pm 0.03 c$ & $1.91 \pm 0.01 b$ & $1.75 \pm 0.04 d$ \\
\hline Feed efficiency (FE) & $0.51 \pm 0.005$ & $0.53 \pm 0.007$ & $0.52 \pm 0.003$ & $0.51 \pm 0.010$ \\
\hline PER & $1.70 \pm 0.005 \mathrm{c}$ & $1.78 \pm 0.02 \mathrm{a}$ & $1.74 \pm 0.01 \mathrm{~b}$ & $1.70 \pm 0.03 c$ \\
\hline PPV \% & $27.59 \pm 0.005 \mathrm{c}$ & $30.80 \pm 0.46 \mathrm{a}$ & $29.58 \pm 0.22 \mathrm{ab}$ & $28.94 \pm 0.59 \mathrm{bc}$ \\
\hline Energy retention (ER \%) & $48.76 \pm 2.48 \mathrm{a}$ & $30.46 \pm 0.76 \mathrm{c}$ & $33.96 \pm 1.26 b c$ & $44.47 \pm 1.89 \mathrm{a}$ \\
\hline
\end{tabular}

\section{Serum lysozyme: -}

Serum lysozyme activity was significantly increased (p<0.05) with $10 \mathrm{~g} A$. coffeaeformis followed by $20 \mathrm{~g}$ and $30 \mathrm{~g}$ during the experiment and reached to $615.50 \pm 3.30,724.79 \pm 1.07$ and $804.31 \pm 2.82 \mathrm{~g} / \mathrm{ml}$ at the end of experiment respectively when compared with the control group $229.13 \pm 3.10 \mathrm{~g} / \mathrm{ml}$ represented in Table 4 and Fig. 1.

It was clear that serum lysozyme was significantly increased by increasing in the A. coffeaeformis levels in the diet.

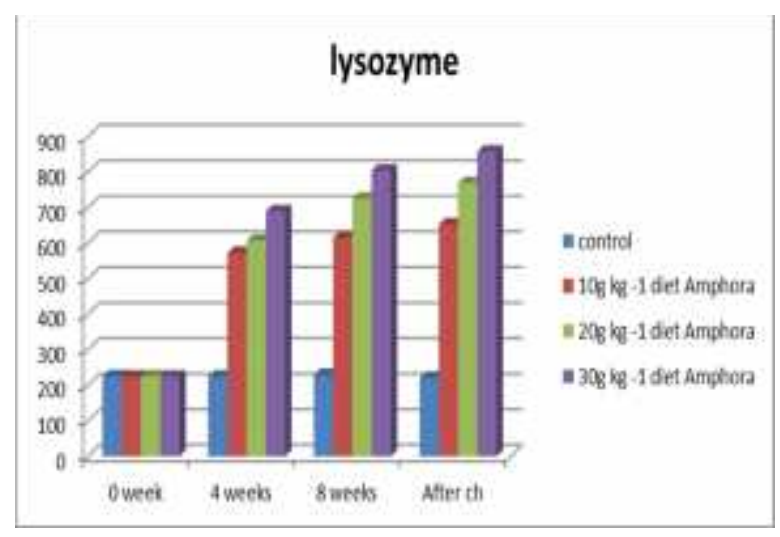

Fig. 1: Lysozyme values ( $\mathrm{g} / \mathrm{ml}$ ) under different treatments fed with A. coffeaeformis during various sampling weeks. 
Table 4: Lysozyme activity, serum protein profile and liver enzymes (Mean $\pm \mathrm{SE}$ ) of Nile tilapia as affected by different concentrations of $A$. coffeaeformis.

\begin{tabular}{ccccc}
\hline Parameters & T1 (Control) & T2 & T3 & T4 \\
\hline Lysozyme activity ( g/ml) & $229.13 \pm 3.10 \mathrm{~d}$ & $615.50 \pm 3.30 \mathrm{c}$ & $724.79 \pm 1.07 \mathrm{~b}$ & $804.31 \pm 2.82 \mathrm{a}$ \\
Total protein (g/dL) & $2.31 \pm 0.05 \mathrm{c}$ & $3.82 \pm 0.04 \mathrm{~b}$ & $3.94 \pm 0.02 \mathrm{~b}$ & $4.28 \pm 0.3 \mathrm{a}$ \\
Albumin (g/dL) & $0.82 \pm 0.15 \mathrm{~b}$ & $1.24 \pm 0.01 \mathrm{a}$ & $1.22 \pm 0.01 \mathrm{a}$ & $1.33 \pm 0.01 \mathrm{a}$ \\
Globulin (g/dL) & $1.49 \pm 0.13 \mathrm{~b}$ & $2.58 \pm 0.04 \mathrm{a}$ & $2.71 \pm 0.02 \mathrm{a}$ & $2.95 \pm 0.03 \mathrm{a}$ \\
A/G Ratio & $55.1 \pm 0.1 \mathrm{a}$ & $48.1 \pm 0.1 \mathrm{~b}$ & $45.1 \pm 0.4 \mathrm{c}$ & $45.1 \pm 0.2 \mathrm{c}$ \\
ALT (U/I) & $20.76 \pm 0.33$ & $20.78 \pm 0.33$ & $20.84 \pm 0.30$ & $20.78 \pm 0.34$ \\
AST(U/I) & $42.14 \pm 0.13$ & $42.16 \pm 0.15$ & $42.16 \pm 0.12$ & $42.25 \pm 0.06$ \\
\hline
\end{tabular}

The different letter in the same row is significantly different at. $(\mathrm{P}<0.05)$.

\section{Serum protein profile: -}

Total protein, albumin, and globulin in fish sera were significantly affected by the concentration of Amphora. Total protein increased by increasing A. coffeaeformis ( $\mathrm{P}<0.05)$. The highest value was $4.28 \pm 0.3 \mathrm{~g} / \mathrm{dLand}$ the lowest value was $2.31 \pm 0.05$ $\mathrm{g} / \mathrm{dL}$ (Table 4 and Fig. 2).Serum albumin and globulin were observed at $30 \mathrm{~g}$ of $A$. coffeaeformis $1.33 \pm 0.01$ and $2.95 \pm 0.03 \mathrm{~g} / \mathrm{dL}$ respectively as in table 4 , Figs. 3 and 4 .

The A/ G ratio showed a decreasing trend over the period with the lowest value being recorded in groups that fed with $A$. coffeaeformis $\mathrm{kg}-1$ diet (Table 4 and Fig. $5)$.

Additionally, serum ALT and AST were within normal values in all treatment groups treated with A. coffeaeformis when compared with the control group.

The values of ALT were observed at the end of the experiment in 10, 20 and 30 $\mathrm{g} / \mathrm{kg}$ A. coffeaeformis group and control group (20.78 $\pm 0.33,20.84 \pm 0.30,20.78 \pm 0.34$ and $20.76 \pm 0.33 \mathrm{U} / \mathrm{I}$, respectively). Meanwhile, the values of serum AST were $(42.16 \pm 0.15,42.16 \pm 0.12,42.25 \pm 0.06$ and $42.14 \pm 0.13 \mathrm{U} / \mathrm{I}$, respectively) (Table 4, Figs. 6 and 7).

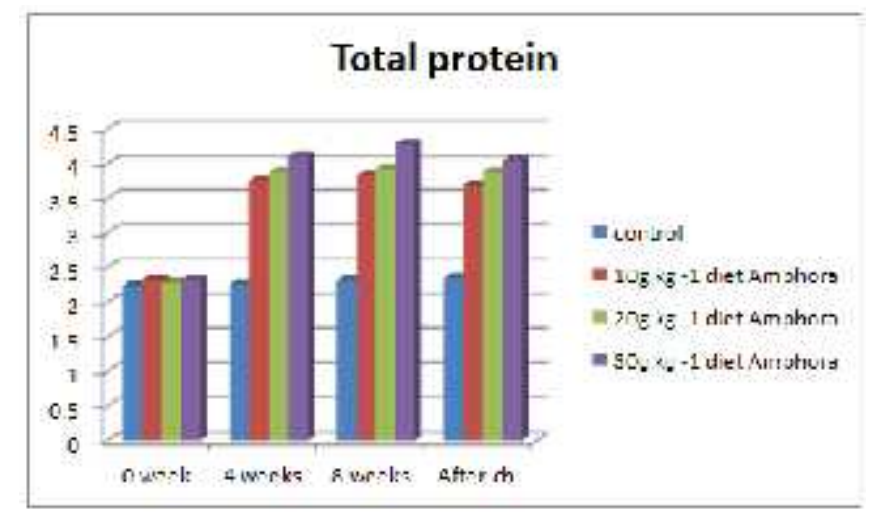

Fig. 2:Total protein values $(\mathrm{g} / \mathrm{dL})$ under different treatments fed with A. coffeaeformis during various sampling weeks. 


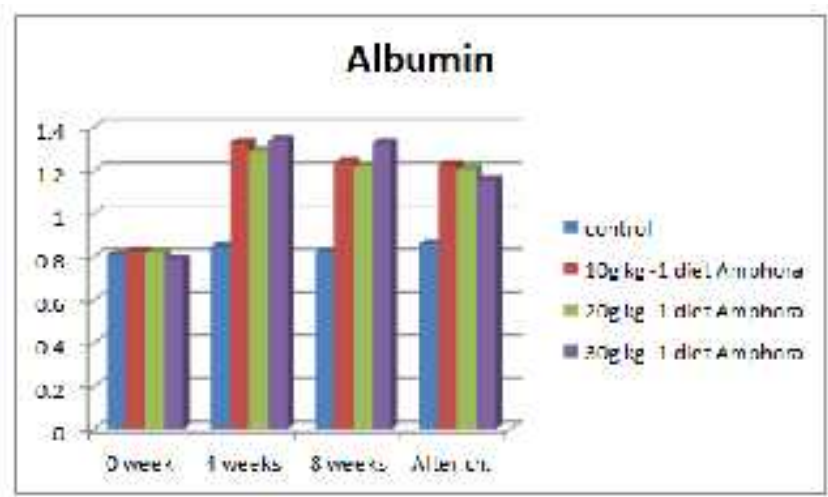

Fig. 3: Albumin values (g/dL) under different treatments fed with A. coffeaeformis during various sampling weeks.

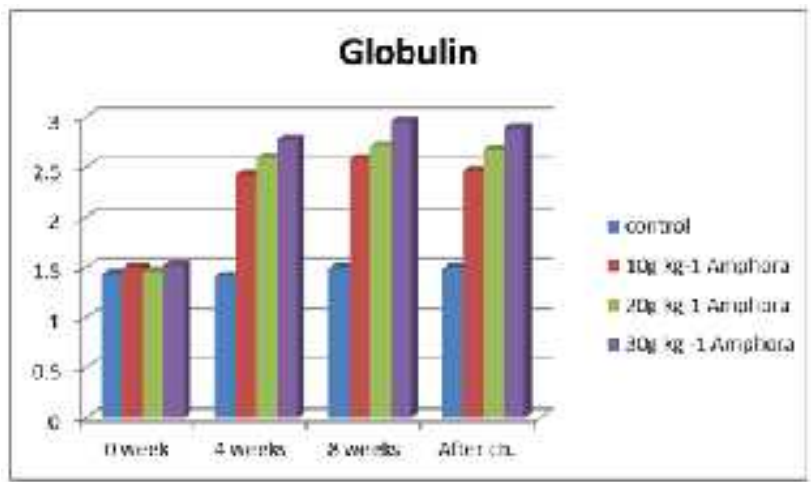

Fig. 4: Globulin values $(\mathrm{g} / \mathrm{dl})$ under different treatments fed with A. coffeaeformis during various sampling weeks.

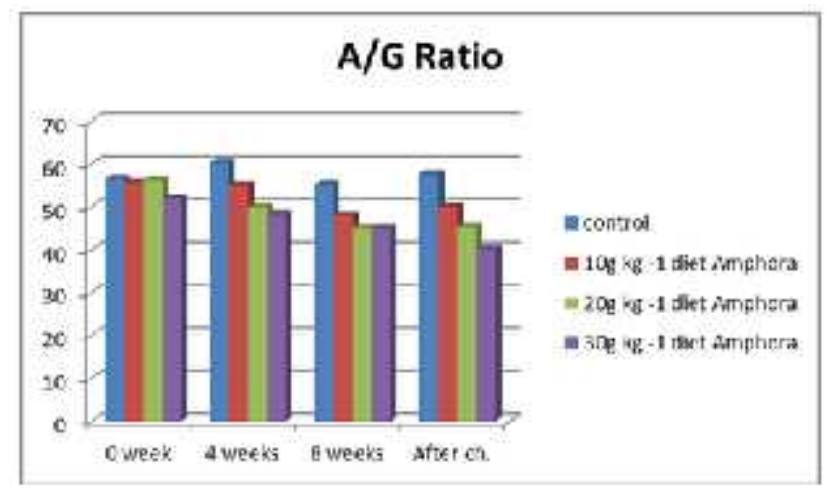

Fig. 5: Albumin/globulin ratio of different treatments fed with A. coffeaeformis during various sampling weeks. 


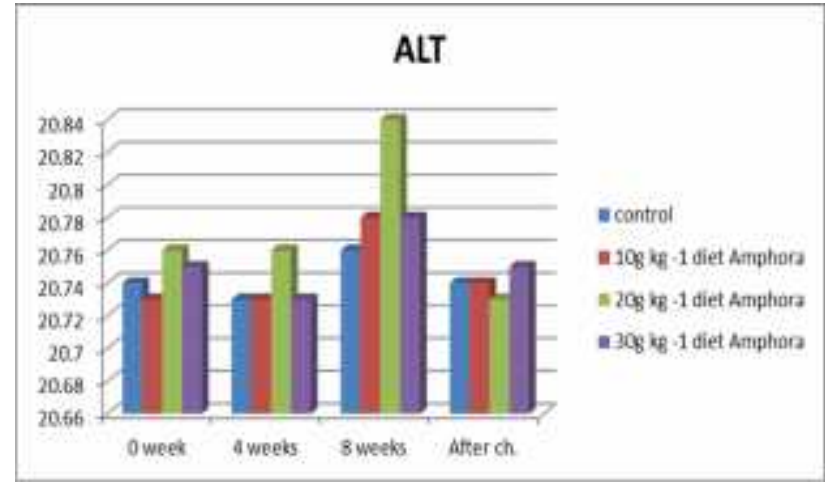

Fig. 6: ALT values (U/I) under different treatments fed with A. coffeaeformis during various sampling weeks.

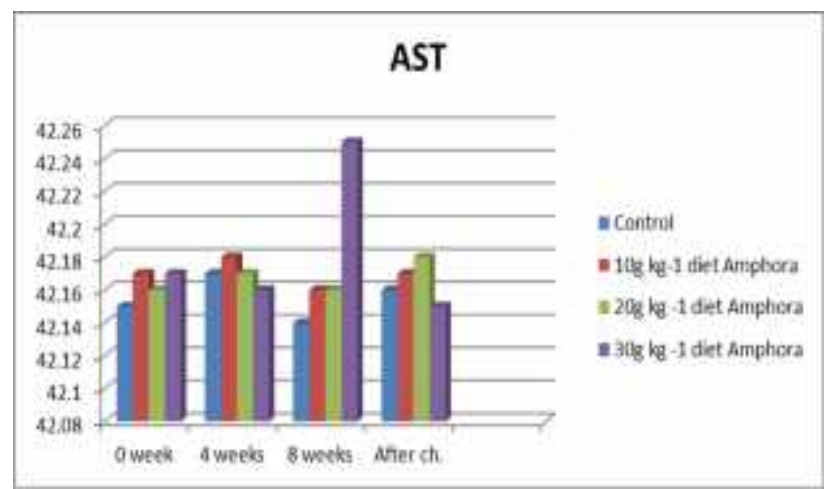

Fig. 7: AST values $((\mathrm{U} / \mathrm{I}))$ under different treatments fed with A. coffeaeformis during various sampling weeks

\section{Challenge test:}

Significant protection was shown in the A. coffeaeformis treated tilapia treatments after challenge with A. hydrophila. The results showed that the T4 treatment gave a higher level of RPS (89\%) for the fish than T3 $(86 \%)$ and T2 $(78 \%)$ compared to the fish of the T1 control $(0 \%)$ as in Table 5.

Table 5: The relative percentage of survival (RPS) of different treatments fed with A. coffeaeformis groups compared with the control group after the challenge test.

\begin{tabular}{cccccc}
\hline Treatments & No. of fish & Dead & Survival & Mortality \% & RPS \% \\
\hline T1 & 30 & 27 & 3 & 90 & 0 \\
T2 & 30 & 6 & 24 & 20 & 78 \\
T3 & 30 & 4 & 26 & 13.33 & 86 \\
T4 & 30 & 3 & 27 & 10 & 89 \\
\hline
\end{tabular}

\section{DISCUSSION}

Fish fed a diet supplemented with A. coffeaeformis showed significantly better growth and feed utilization. The supplementation of A. coffeaeformis significantly affected the protein and lipid contents in the whole-fish body. The better feed intake in A. coffeaeformis enriched diets may have been due to the increased fish appetite, resulting in higher feed intake and improved growth. On the other hand, changes in 
the protein and lipid contents in the fish body could be linked to changes in their synthesis, deposition rate in muscle and/or different growth rates (Smith, 1981 \& Soivio et al., 1989).

In the present study, fish fed a diet containing A. coffeaeformis could enhance fish growth and immunity like other organisms such as brewer's yeast (Saccharomyces cerevisiae), which had been reported to enhance the growth and immunity of Nile tilapia, O. niloticus (Abdel-Tawwab et al., 2008). Similarly, Abdel-Latif and Khalil (2014) have documented that the use of Spirulina platensis $(2.5,5 \& 10 \%)$ and origanum vulgare extract $(5 \& 10 \%)$ as feed additives in tilapia diets have significantly improved the growth parameters, protein $\%$ in muscles and resistance to Vibrio alginolyticus infection.

The improved fish growth and feed utilization, on supplementation with $A$. coffeaeformis, may possibly be due to the improved feed intake and nutrient digestibility. Otherwise, A. coffeaeformis contains several nutrients, especially vitamins and minerals, that may aid growth promotion. These results were like the findings of Belay et al. (1996).

The present study showed that the addition of the A. coffeaeformis to the diets of Nile tilapia improved the lysozyme, serum protein and increased disease resistance of fish. Lysozyme, detected in the blood, mucus and organs of various fish, plays on an important bactericidal role in the non - specific defense against pathogens primarily through lytic actions on the pathogen cell wall. High lysozyme activity may be desirable in cultured fish because it may aid against infection when fish are kept at high densities and consequently are exposed to high bacterial loads (Grinde et al., 1988).

In this study, significantly higher lysozyme activities were detected for supplementation levels of $A$. coffeaeformis compared to control one, that supported by Pirarat et al. (2006) using a probiotic bacterium Lactobacillus rhamnosus in $O$. niloticus diets. Fish mostly rely on innate immunity in comparison to mammals (Swain et al., 2007). Accordingly, great attention has been focused on the use of dietary bioactive materials to stimulate innate immunity (Ragab et al., 2012).

Proteins are the most important component in the serum and are also termed as circulating mobile proteins. The serum proteins are divided into two groups, albumin, and globulins. Increase in the serum protein, albumin and globulin levels is considered a stronger innate response in fishes (Wiegertjes et al., 1996). In the present study, fish fed a diet containing A. coffeaeformis exhibited higher total protein, albumin and globulin as compared with that fed the control diet and these results reflect the immune potentiating effect of probiotics and agreed with Johnston et al. (1989), who mentioned that the increase in the total proteins may be due to the increase in the palatability, digestibility, and absorbability, hence, increased food consumption of the probiotic-containing diet. However, a significantly lower albumin-globulin $(\mathrm{A} / \mathrm{G})$ ratio observed indicates the presence of more amounts of globulin in the treatment groups compared with control. These results indicate an improvement in fish health when fed on A. coffeaeformis enriched diets. Moreover, the measurement of albumin, globulin and total protein in serum is of considerable diagnostic value in fish, as it relates to the general nutritional status as well as the integrity of the vascular system and liver function (Schaperclaus et al., 1992).

Besides, there was no significant change in activities of hepatic transaminase enzymes (ALT and AST) in all treatment groups during 4 and 8 weeks and postchallenge. 
It is important to estimate the relative level of protection in the treated fish to determine the efficacy of an immunostimulant. The supplemented diet with $A$. coffeaeformis groups reduced mortality induced by A. hydrophila when compared with the control group. These results indicate that the A. coffeaeformis activated the immune system of the Nile tilapia (O. niloticus) and it became resistance to pathogenic bacteria. These results were in concordance with the finding with Watanuki et al. (2006) and Ragab et al. (2012) who estimated the fluctuation in the number of bacterial cells in Spirulina-treated fish organs after bacterial challenge with A. hydrophila. They found that the bacteria numbers were lower in the liver and kidney of carp treated with Spirulina than the control group, suggesting the increased resistance of carp orally treated with Spirulina to A. hydrophila infection.

\section{CONCLUSION}

The present study clearly indicates that the oral administration of $A$. coffeaeformis at three concentration of $(10,20$ and $30 \mathrm{~g} / \mathrm{kg}$ diet $)$ in Nile tilapia $(O$. niloticus) diets leads to enhance the growth performance, feed efficiency, serum lysozyme activity and improved total protein, albumin and globulin. Besides, the decrease in albumin and globulin ratio. Moreover, no significant changes in liver function enzymes. These appear to be a significant role for the control of bacterial diseases and the optimum level of $A$. coffeaeformis in the fish diet should be ranged between 10 to $20 \mathrm{~g} \mathrm{~kg}^{-1}$ diet.

\section{ACKNOWLEDGEMENT}

The authors would like to thank the members of the Fish Production Department, faculty of Agriculture , Al Azhar University and Fish health and diseases department of the central laboratory for Aquaculture Research for their help during the running of this study.

\section{REFERENCES}

Abdel-Latif, H.M.R. and Khalil, R.H. (2014). Evaluation of two Phytobiotics, Spirulina platensis, and Origanum vulgare extract on Growth, Serum antioxidant activities and Resistance of Nile tilapia ,Oreochromis niloticus to pathogenic Vibrio alginolyticus. International Journal of Fisheries and Aquatic Studies, 1(5): 250-255.

Abdel-Tawwab, M. and El-Marakby, H.I. (2004). Length-weight relationship, natural food and feeding selectivity of Nile tilapia; Oreochromis niloticus (L.) in fertilized earthen ponds In The $6^{\text {th }}$ International Symposium of Tilapia in Aquaculture (ed. by R. Bolivar, G. Mair\& K. Fitzsimmons), pp.500-509. Philippine International Convention Center, Roxas Boulevard, Manila, Philippines.

Abdel-Tawwab, M.; Abdel-Rahman, A.M. and Ismael, N.E. (2008). Evaluation of commercial live bakers' yeast, Saccharomyces cerevisiae as a growth and immunity promoter for Fry Nile tilapia, Oreochromis niloticus (L.) challenged in situ with Aeromonas hydrophila. Aquaculture, 280(1-4), 185-189.

Abu-Elala, N.; Abdelsalam, M.; Marouf, S. and Setta, A. (2015). Comparative analysis of virulence genes, antibiotic resistance and gyrB-based phylogeny of 
motile Aeromonas species isolates from Nile tilapia and domestic fowl. Lett Appl. Microbiol., (61): 429-436.

Amend, D.F. (1981). Potency testing of fish vaccines. Fish biologics: serodiagnostics and vaccines.

Amin, E.D.N.; Abdel-krim, I.S.; Elallawy Y.T. and Ahmed, S.M. (1985). Motile Aeromonas septicemia among Tilapia nilotica (Sarothredon niloticus) in Upper Egypt. Fish Pathol., 20 (213): 93-97.

AOAC, (1990). Official Methods of Analysis of the Association of Official Analytical Chemists, $15^{\text {th }}$ edn. Association of Official Analytical chemists, Arlington, VA.

Barros, M.P.; Pinto, E.; Sigaud-Kutner, T.C.S.; Cardozo, K.H.M. and Colepicolo, P. (2005). Rhythmicity and oxidative/nitro-sative stress in algae. Biol Rhythm Res., 36(1-2):67-82.

Belay, A.; Kato, T. and Ota, Y. (1996). Spirulina (Arthrospira): Potential application as an animal feed supplement. International Association of Applied Algology, 7th International Conference Abstracts, p. 23.

Bhosleac, N.B.; Evansad, L.V. and Edyveanb, R.G.J. (1993). Carbohydrate production by Amphora coffeaeformis, a marine fouling diatom. Biofouling, 7(1):81-91.

Dhar, B.C.; Cimarelli, L.; Singh, K.S.; Brandi, L.; Brandi, A.; Puccinelli, C.; Marcheggiani, S. and Spurio, R. (2015). Molecular detection of a potentially toxic diatom species. Int J Environ Res Public Health, 12(5):4921-4941.

Doumas, B.T.; Watson, W.A.; and Biggs, H.G. (1971). Albumin standards and the measurement of serum albumin with bromocresol green. Clin. Chim. Acta, (31): 87-96.

El-Sayed A.F.M. (2006). Tilapia Culture. CABI Publishing, Willingford, Oxford shire, UK.

Enwereuzoh, U.O. and Onyeagoro, G.N. (2014). A novel aeration method for the Preparation of algae (Dunaliella Salina) biomass for biofuel production. Am. J. Eng. Res., 3(9):209-214.

Gatesoupe, F.J. (1999). The use of probiotics in aquaculture. Aquaculture, (180):147165.

Getabu, A. (1994). A comparative study on the feeding habits of Oreochromis niloticus (Linnaeus) in Nyanza Gulf Lake Victoria and sewage fish ponds. In: Proceedings of the Second EEC Regional Seminar on Recent Trends of Research on Lake Victoria Fisheries (ed. by E. Okemwa, E.O. Wakwabi \& A. Getabu), pp.93-103. ICIPE Science, Nairobi, Kenya.

Grinde, B.; Lie, O.; Poppe, T. and Salte, R. (1988). Species and individual variation in lysozyme activity in fish of interest in aquaculture. Aquaculture, (68): 299 304.

Henry, R.J. (1964). Colorimetric determination of total protein. In Clinical Chemistry, p. 181. New York: Harper \& Row.

Irianto, A. and Austin, B. (2002). Use of probiotics to control furunculosis in rainbow trout, Oncorhynchus mykiss (Walbaum). Journal of Fish Diseases, (25): 333-342.

Johnston, C.E.; Gray, R.W.; McLennan, A. and Paterson, A. (1989). Effects of photoperiod, temperature and diet on the reconditioning response, blood chemistry and gonad mutation of Atlantic salmon kelts (Salmo salar) held in fresh water. Candian J. of Fishes and Aquatic Sci., (44): 702-711. 
Lied, E.; Gezrde, Z. and Braskan, O.R. (1975). Simple and rapid technique for repeated blood sampling in rainbow trout. J. Fish. Res. Board of Canada, (32): 699-701.

Pirarat, N.; Kobayashi, T.; Katagiri, T.; Maita, M. and Endo, M. (2006). Protective effects and mechanisms of a probiotic bacterium Lactobacillus rhamnosus against experimental Edwardisella tarda infection in tilapia (O. niloticus). Vet. Immunol. and Immunopathol., (113): 339-347.

Ragab, H.M.; Khalil, R.H. and Mutawie, H.H. (2012). Immunostimulant effects of dietary Spirulina platensis on tilapia, Oreochromis niloticus. Journal of Applied Pharmaceutical Science, 2 (2): 26-31.

Reitman, S. and Frankel, S. (1957). A colorimetric method for determination of serum glutamate oxaloacetic acid and pyruvic acid transaminases. Am. J. Clin. Pathol., (29):56-63.

Schaperclaus, W.; Kulow, H. and Schreckenbach, K. (1992). Fish Disease. A.A. Balkema, Rotterdam, the Netherlands.

Schltz, L.A. (1987). "Veterinary Haematology". 3rd ed., Lea and Febiger.; 39(2): 217-222.

Selim, K.M. and Reda, R.M. (2015). Improvement of immunity and disease resistance in the Nile tilapia, Oreochromis niloticus, by dietary supplementation with Bacillus amyloliquefaciens. Fish and Shellfish Immunol., (44): 496-503.

Selvendran, M. (2013). Studies on antimicrobial compounds from selected marine phytoplanktons. Int. J. Pharm. Bio. Sci., 4(2):876-888.

Serrano, P.H. (2005). Responsible use of antibiotics in aquaculture (No. 469). Food $\&$ Agriculture Org.

Smith, M.A.K. (1981). Estimation of growth potential by measurement of tissue protein synthetic rates in feeding and fasting rainbow trout, Salmo gairdneri Richardson. Journal of Fish Biology 19: 213-220.

Soivio, A.; Niemisto, M. and Backstrom, M. (1989). Fatty acid composition of Coregonus muksun Pallas: changes during incubation, hatching, feeding and starvation. Aquaculture, 79: 163-168.

Swain, P.; Dash, S.; Sahoo, P.K.; Routray, P.; Sahoo, S.K.; Gupta, S.D.; Meher, P.K. and Sarangi, N. (2007). Non-specific immune parameters of brood Indian major carp Labeo rohita and their seasonal variations. Fish Shellfish Immunol., 22: 38-43.

Watanuki, H.; Ota, K.; Malin, A.C.; Tassakka, A.R.; Kato, T. and Sakai, M. (2006). Immunostimulant effects of dietary Spirulina platensis on carp, Cyprinus carpio. Aquaculture, 258:157-163.

Wiegertjes, G.F.; Stet, R.J.M.; Parmeatier, H.K. and Van Muiswinkel, W.B. (1996). Immunogenetics of disease resistance in fish: a comparable approach developmental and comparative immunology. J. Exp. Boil., (20): 365e81.

Zaki, V.H. (1991). Some studies on motile Aeromonas in freshwater fish with special emphasis to their toxigenic profile. M.V.Sc. Thesis, Fac. Vet. Med., Alex. Univ. 


\section{ARABIC SUMMARY}

تاثير اضافه طحلب الامفورا كمفيفورمس في علائق اسماك البلطي النيلي على اداء النمووالمناعه الغير

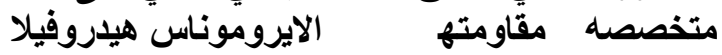

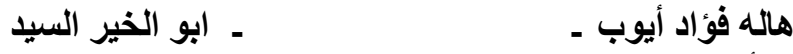

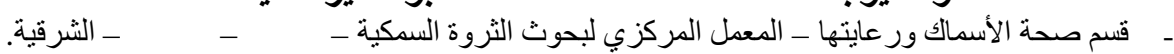

$$
\begin{aligned}
& \text { ـ - قسم انتاج الاسماك كليه الزر اعه جامعه الاز هر }
\end{aligned}
$$

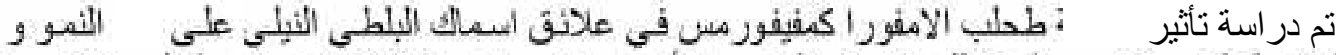

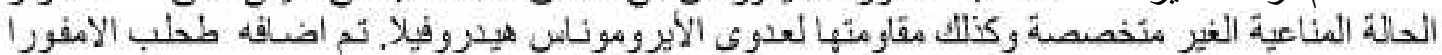

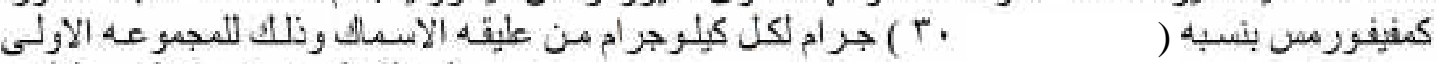

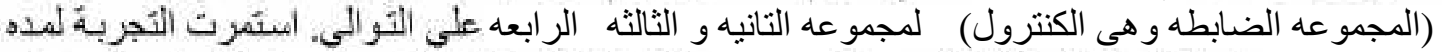

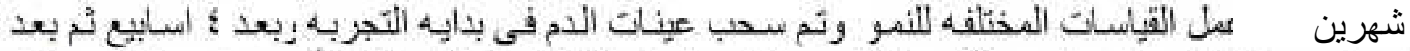

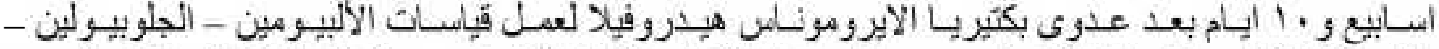

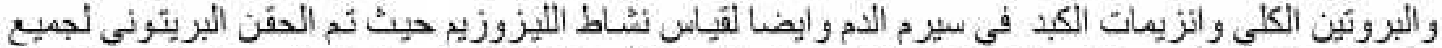

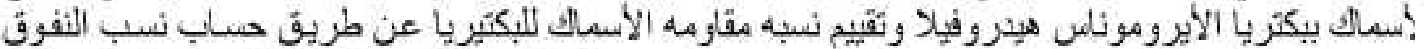

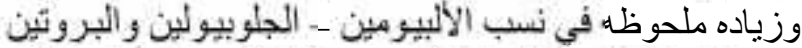

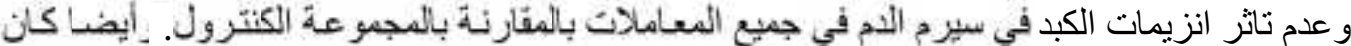

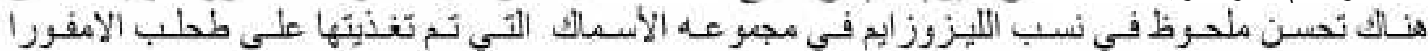

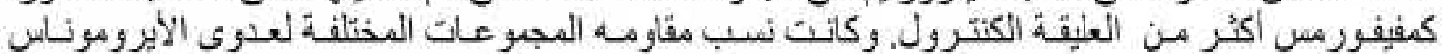

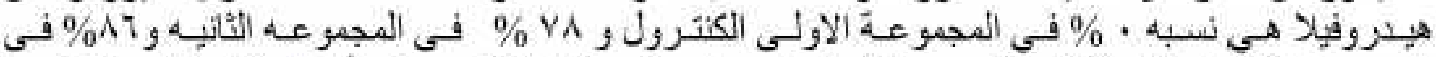

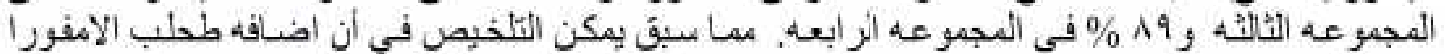
كمفيفورمس فى علائق اسماك البلطى النيلى يحسن من اداء النمو و الحاله المناعيه ومقاومه الان الإن 